\title{
Immunogenicity of Haemophilus Influenzae Type b Conjugate Vaccines in Infant Rhesus Monkeys
}

\author{
PHILIP P. VELLA AND RONALD W. ELLIS \\ Department of Cellular and Molecular Biology, Merck Sharpe and Dohme Research Laboratories, West Point, \\ Pennsylvania 19486
}

\begin{abstract}
Two Haemophilus influenzae type b (Hib) polysaccharide-protein conjugate vaccines were evaluated for immunogenicity in eliciting anti-polyribosyl ribitol phosphate (PRP) antibodies in infant rhesus monkeys. Animals received intramuscular injections of either Hib polysaccharide (PRP)-meningococcal outer membrane protein complex or Hib oligosaccharide-CRM ${ }_{197}(\mathrm{HbOC})$ conjugate vaccines on d 0,28 , and 56 . Because $\mathrm{HbOC}$ contains the $\mathrm{CRM}_{197}$ mutant diphtheria toxin from Corynbacterium diphtheriae as its protein carrier, the effect of simultaneous injection of diphtheria toxoid on the immunogenicity of $\mathrm{HbOC}$ also was evaluated by dividing monkeys vaccinated with $\mathrm{HbOC}$ into three groups: $\mathrm{HbOC} / \mathrm{saline}, \mathrm{HbOC} / \mathrm{diph}$ theria and tetanus toxoids, and $\mathrm{HbOC} /$ tetanus toxoid (coadministration of $\mathrm{HbOC}$ and other vaccine or placebo injected into the flank muscle of different legs). Infant monkeys vaccinated with the PRP-outer membrane protein complex conjugate responded with anti-PRP antibody after the first dose and showed booster responses after the second and third injections. In contrast, infant monkeys vaccinated with $\mathrm{HbOC}$ did not respond after three doses of $\mathrm{HbOC} / \mathrm{saline}$ or $\mathrm{HbOC} /$ tetanus toxoid. However, two of three monkeys given concurrent injections of $\mathrm{HbOC}$ and diphtheria and tetanus toxoids did respond. The nonresponder monkey to three doses of $\mathrm{HbOC}$ and diphtheria and tetanus toxoids did respond to a subsequent injection with PRP-outer membrane protein complex. Thus, concomitant administration of diphtheria toxoid, a common vaccine for human infants, is necessary to elicit an antiPRP antibody response to $\mathrm{HbOC}$. This finding suggests that the $\mathrm{CRM}_{197}$ protein, at the 12.5- $\mu \mathrm{g}$ dose of protein in the HbOC used in this study, may not be sufficiently immunogenic in naive infant rhesus monkeys to permit an antibody response to the Hib oligosaccharide component of the conjugate. (Pediatr Res 29: 10-13, 1991)
\end{abstract}

\section{Abbreviations}

Hib, Haemophilus influenzae type b PRP, polyribosyl ribitol phosphate

OMPC, outer membrane protein complex

DT, diphtheria and tetanus toxoid

D, diphtheria toxoid

$T$, tetanus toxoid

AU, antitoxin unit

DTP, diphtheria, tetanus, pertussis vaccine

HbOC, Hib oligosaccharide $\mathrm{CRM}_{197}$

Lf, limes flocculation

Received July 12, 1990; accepted September 18, 1990

Correspondence and reprint requests: Philip P. Vella, Merck Sharp and Dohme Research Laboratories, West Point, PA 19486.
Hib causes an estimated 10000 meningitis cases annually in the United States, primarily in children 2 mo to 5 y old (1-4). The mortality rate due to Hib meningitis ranges from 5 to $10 \%$, with about $40 \%$ of the survivors developing some degree of permanent neurologic impairment. Other invasive infections involve epiglottitis, septicemia, osteomyelitis, septic arthritis, otitis media, pneumonia, and pericarditis, bringing the total number of Hib disease cases to an estimated 30000 annually. Approximately half of the disease cases occur during the first year of life. Antibody to the Hib capsular polysaccharide (PRP) is protective (5-7). A vaccine-induced antibody level of $1.0 \mu \mathrm{g}$ anti-PRP $/ \mathrm{mL}$ has been correlated with long-term protection (8). Children less than 18-24 mo old do not respond to T-independent antigens such as PRP unless the antigen is conjugated to a $T$-dependent carrier protein. New vaccines exist consisting of PRP conjugated to a carrier protein(s), whereby the anti-PRP response is converted to T-dependency. Our report compares the immunogenicity of two $\mathrm{Hib}$ conjugate vaccines in an infant rhesus monkey model that to date has been predictive of the immunogenicity of one of the conjugates in human infants (9).

\section{MATERIALS AND METHODS}

Monkeys. Groups of three rhesus monkeys (Macaca mulata), 2-3 mo old of both sexes, were immunized intramuscularly with $0.25-\mathrm{mL}$ doses of vaccine or saline placebo into the flank of each leg $(0.5 \mathrm{~mL}$ total volume $)$. The small number of animals in each group was dictated by limited availability of the animals. Unless noted otherwise, vaccination was given on d 0,28 , and 56. Infants were housed individually with their mothers at the New Iberia Research Center, Southwestern Louisiana University, New Iberia, Louisiana.

Vaccines. Hib polysaccharide-meningococcal OMPC conjugate vaccine (PedvaxHIB, Merck Sharp and Dohme, West Point, PA) contains PRP covalently coupled to an OMPC from Neisseria meningitidis serogroup B by a thioether linkage (10). Hib oligosaccharide-CRM ${ }_{197}$ conjugate vaccine (HibTITER, Praxis Biologics, Rochester, NY) contains Hib oligosaccharides coupled by reductive amination to a carrier protein $\left(\mathrm{CRM}_{197}\right)$ that is a nontoxic mutant of diphtheria toxin (11). These two vaccines are referred to herein as PRP-OMPC and HbOC, respectively.

PRP-OMPC conjugate vaccine (lot $R \times 42593$ ) contains $15 \mu \mathrm{g}$ of PRP and $177 \mu \mathrm{g}$ of OMPC adsorbed to $0.225 \mathrm{mg}$ aluminum hydroxide in $0.5 \mathrm{~mL}$. In a separate study, a second vaccine (lot 1080) adsorbed to aluminum hydroxide was tested at lower doses of PRP: $1.0,0.2$, and $0.04 \mu \mathrm{g}$ containing $16.9,3.4$, and $0.7 \mu \mathrm{g}$ of OMPC, respectively, to demonstrate its immunogenicity range. $\mathrm{HbOC}$ (lot M620K) contains $10 \mu \mathrm{g}$ of PRP and $25 \mu \mathrm{g}$ of CRM $\mathrm{CR}_{197}$ protein $/ 0.5 \mathrm{~mL}$. HbOC was administered as a $0.25-\mathrm{mL}$ dose in one leg and $0.25 \mathrm{~mL}$ of physiologic saline in the other. The resulting 5- $\mu \mathrm{g}$ oligosaccharide dose of HbOC per monkey was selected to limit the volume/leg to $0.25 \mathrm{~mL}$ based on humane considerations, and because serologic data from humans has shown that even 2- $\mu \mathrm{g}$ doses of HbOC are immunogenic (12). 
Additional groups of monkeys had $0.25 \mathrm{~mL} \mathrm{HbOC}$ administered in one leg and $0.25 \mathrm{~mL}$ of either DT (diphtheria, $6.25 \mathrm{Lf}$ units; tetanus, 2.5 Lf units) (lot no. 244-915, Lederle Labs, Pearl River, NY) or T (Lederle Labs, lot no. 250-922) injected into the opposite leg. One of the monkeys in the HbOC/DT group was injected with PRP-OMPC containing $1.0 \mu \mathrm{g}$ of PRP and $11.8 \mu \mathrm{g}$ of OMPC ( $0.25 \mathrm{~mL}$ into the flank muscle of each leg) on d 96 ; this animal was bled immediately before this injection and on $d$ 128.

Serology. Blood samples were taken on d $0,28,42,56$, and 84 unless noted otherwise. Antibody responses to PRP were measured in a RIA procedure (9) using extrinsically labeled ${ }^{125}$ I-PRP (from Hib strain Ross) and quantitated using an FDA standard serum (Office of Biologics Research and Review, 1983). This Hib assay is very similar to that used by most laboratories and, although there are exceptions, such RIA data are comparable to results from the Finnish laboratories (13). In our study, responders were considered those infant rhesus monkeys that achieved anti-PRP antibody concentrations $\geq 1.0 \mu \mathrm{g} / \mathrm{mL}$. Sera were submitted to Advanced Allergy Management Laboratory for anti-D and anti-T determinations using ELISA methods where $\mathrm{D}$ or $\mathrm{T}$ are noncovalently bound to the polyvinyl surface of microtiter plates (14). Alkaline phosphatase conjugated antihuman IgG and a p-nitrophenyl phosphate substrate are used. The results are obtained from standard curves based on United States Bureau of Standards reference sera and titers are expressed as the number of antitoxin units $/ \mathrm{mL}$.

Table 1. Anti-PRP antibody responses $(\mu \mathrm{g} / \mathrm{mL})$ of infant rhesus monkeys to $\mathrm{HbOC}$ conjugate vaccine in relation to simultaneous vaccination with $D T$

\begin{tabular}{|c|c|c|c|c|c|c|}
\hline \multirow[b]{2}{*}{ Vaccine } & \multirow{2}{*}{$\begin{array}{l}\text { Dose PRP or } \\
\text { oligosaccharide } \\
\text { ( } \mu \mathrm{g} / \text { monkey)* }\end{array}$} & \multicolumn{5}{|c|}{ Bleeding day } \\
\hline & & 0 & 28 & 42 & 56 & 84 \\
\hline \multirow[t]{3}{*}{$\mathrm{HbOC} /$ saline } & 5.0 & $<0.1$ & $<0.1$ & $<0.1$ & $<0.1$ & 0.4 \\
\hline & & 0.2 & 0.3 & 0.4 & 0.2 & 0.3 \\
\hline & & $<0.1$ & $<0.1$ & $<0.1$ & $<0.1$ & 0.3 \\
\hline \multirow[t]{3}{*}{$\mathrm{HbOC} / \mathrm{T}$} & 5.0 & $<0.1$ & $<0.1$ & $<0.1$ & 0.1 & 0.1 \\
\hline & & $<0.1$ & $<0.1$ & $<0.1$ & $<0.1$ & $<0.1$ \\
\hline & & $<0.1$ & $<0.1$ & 0.4 & 0.4 & 0.3 \\
\hline \multirow[t]{3}{*}{$\mathrm{HbOC} / \mathrm{DT}$} & 5.0 & $<0.1$ & 0.9 & 37.1 & 32.1 & 65.5 \\
\hline & & $<0.1$ & 0.2 & 0.1 & 0.2 & $<0.1$ \\
\hline & & $<0.1$ & $<0.1$ & 7.1 & 5.6 & 15.1 \\
\hline \multirow[t]{3}{*}{ PRP-OMPC } & 15.0 & $<0.1$ & 120.9 & 245.7 & 158.3 & 104.3 \\
\hline & & $<0.1$ & 0.4 & 8.6 & 6.9 & 53.7 \\
\hline & & $<0.1$ & 0.2 & 3.1 & 1.9 & 9.7 \\
\hline
\end{tabular}

${ }^{*}$ Animals were vaccinated on $\mathrm{d} 0,28$, and 56 . The dose of protein administered with $\mathrm{HbOC}$ was $12.5 \mu \mathrm{g} /$ monkey, and for PRP-OMPC the dose was $177 \mu \mathrm{g} /$ monkey.

Table 2. Anti-PRP antibody responses $(\mu \mathrm{g} / \mathrm{mL})$ of infant rhesus monkeys vaccinated with different doses of PRP-OMPC conjugate vaccine

\begin{tabular}{lcrrrr}
\hline \multicolumn{2}{c}{$\begin{array}{c}\text { Dose } \\
(\mu \mathrm{g} / \text { monkey })^{*}\end{array}$} & & \multicolumn{3}{c}{ Bleeding day } \\
\cline { 5 - 6 } PRP & OMPC & & \multicolumn{1}{c}{0} & \multicolumn{1}{c}{28} & \multicolumn{1}{c}{42} \\
\hline 1.0 & 16.9 & $<0.1$ & 299.8 & 420.6 \\
& & 0.2 & 3.1 & 15.6 \\
\multirow{2}{*}{0.2} & \multirow{2}{*}{3.4} & $<0.1$ & 1.5 & 20.3 \\
& & $<0.1$ & 43.2 & 191.7 \\
& & $<0.1$ & 34.6 & 44.3 \\
0.04 & 0.7 & $<0.1$ & 4.8 & 24.5 \\
& & $<0.1$ & 16.3 & 320.7 \\
& & $<0.1$ & 0.7 & 128.0 \\
& & $<0.1$ & $<0.3$ & 0.5 \\
\hline
\end{tabular}

* Animals were vaccinated on $\mathrm{d} 0$ and 28 .
RESULTS

None of the infant rhesus monkeys injected with $\mathrm{HbOC}$ alone or $\mathrm{HbOC} / \mathrm{T}$ responded with anti-PRP antibody concentrations of $\geq 1.0 \mu \mathrm{g} / \mathrm{mL}$ after any of the three doses (Table 1). However, after the second dose of HbOC/DT, two of three monkeys did respond with $\geq 1.0 \mu \mathrm{g}$ anti-PRP $/ \mathrm{mL}$ and exhibited a booster response after the third dose. The third monkey did not respond after three injections. Of the two responders, one monkey in the $\mathrm{HbOC} / \mathrm{DT}$ group responded with an anti-PRP titer of $0.9 \mu \mathrm{g} /$ $\mathrm{mL}$ after a single injection, which rose to $37.0 \mu \mathrm{g} / \mathrm{mL}$ after the second injection and $65.5 \mu \mathrm{g} / \mathrm{mL}$ after the third injection. The second monkey had a titer of $7.1 \mu \mathrm{g}$ anti-PRP/mL after the second injection and $15.1 \mu \mathrm{g} / \mathrm{mL}$ after the third injection.

PRP-OMPC was immunogenic in doses ranging from $15 \mu \mathrm{g}$ to as low as $0.04 \mu \mathrm{g}$, with eight of 12 monkeys developing titers $\geq 1.0 \mu \mathrm{g} / \mathrm{mL}$ after the first dose and 11 of 12 responding after the second dose (Tables 1 and 2). The HbOC/DT-vaccinated monkey that did not respond with anti-PRP after three injections did respond to a 1.0 $\mu \mathrm{g}$ dose of PRP-OMPC administered on $\mathrm{d}$ 96; the prevaccination titer on $\mathrm{d} 96$ was $\geq 0.2 \mu \mathrm{g}$ anti-PRP $/ \mathrm{mL}$, whereas the titer was $13.1 \mu \mathrm{g}$ anti-PRP/mL $32 \mathrm{~d}$ later.

All infant rhesus monkeys receiving DT or $\mathrm{T}$ responded with protective levels $(15)$ of anti-D $(\geq 0.01 \mathrm{AU} / \mathrm{mL})$ and anti- $\mathrm{T}(\geq 0.1$ $\mathrm{AU} / \mathrm{mL}$ ) toxoids after two injections (Table 3 ). The HbOC/DT nonresponder monkey did respond with a protective level of anti-D after two doses $(2.2 \mathrm{AU} / \mathrm{mL})$; the other two monkeys responded with protective levels of anti-D after one, two, and three injections $(\geq 3.2 \mathrm{AU} / \mathrm{mL})$. Increased antibody responses were observed after each $D$ injection. However, no anti-D response $(<0.01 \mathrm{AU} / \mathrm{mL})$ was detected in any of the three monkeys vaccinated with $\mathrm{HbOC}$ alone at a dose that contains $12.5 \mu \mathrm{g}$ of the nontoxic mutant diphtheria toxin, $\mathrm{CRM}_{197}$ protein.

\section{DISCUSSION}

After three doses of HbOC alone, infant rhesus monkeys do not show detectable anti-D or anti-PRP antibody responses. However, animals given concurrent administration of $D$ at a separate site do respond to both antigens. These findings suggest a lack of immunogenicity of the dose of $\mathrm{CRM}_{197}$ protein given in this conjugate vaccine in inducing a $\mathrm{T}$-dependent anti-PRP response in these immunologically naive infant rhesus monkeys. These data for anti-D are consistent with previous observations that the immunogenicity of $C R M_{197}$ protein and $D$ are equivalent only if $\mathrm{CRM}_{197}$ is stabilized by formalin treatment (as per D) (16), whereas $\mathrm{CRM}_{197}$ protein is not treated with formalin in the course of the process for preparing $\mathrm{HbOC}$. Human infants normally receive twice the dose of $\mathrm{HbOC}$ vaccine used in our study of infant monkeys, but doses of less than half that used in our study have been reported to be immunogenic (12). The optimal dose of $\mathrm{HbOC}$ in infant rhesus monkeys is not known. Nevertheless, our data suggest that an immunologically naive host, such as a human infant, may require concurrent administration of $\mathrm{D}$ to elicit an effective anti-PRP response to $\mathrm{HbOC}$.

Of the more than 150 infant rhesus monkeys vaccinated with PRP-OMPC in all previous experiments in this laboratory, all have responded with anti-PRP titers $\geq 1.0 \mu \mathrm{g} / \mathrm{mL}$ after two doses of vaccine ( $\geq 0.2 \mu \mathrm{g}$ of polysaccharide per dose) (Vella PP, Ellis $\mathrm{RW}$, unpublished data). These data indicate that all of the infant monkeys tested to date have been able to respond to an Hib conjugate such as PRP-OMPC in the absence of additional carrier priming. OMPC has been shown to induce carrier priming (17). The serum anti-D and anti-T antibody concentrations measured in children (1-4 y old) suggest that some do not receive the full complement of DTP immunizations or are not immunized al all (18). Even in those children receiving three doses of DTP, $10 \%$ were reported not to have developed protective levels of anti-D (18). These results suggest that it might be useful for a conjugate vaccine to be independently immunogenic, i.e. not be 
Table 3. Anti-D and anti-T antibody responses (U/mL) in infant rhesus monkeys injected with HbOC alone or HbOC simultaneous with DT or $T$

\begin{tabular}{|c|c|c|c|c|c|c|c|c|c|c|}
\hline \multirow[b]{3}{*}{ Vaccine* } & \multicolumn{10}{|c|}{ Bleeding day } \\
\hline & \multicolumn{2}{|c|}{0} & \multicolumn{2}{|c|}{28} & \multicolumn{2}{|c|}{42} & \multicolumn{2}{|c|}{56} & \multicolumn{2}{|c|}{84} \\
\hline & D & $\mathrm{T}$ & $\mathrm{D}$ & $\mathrm{T}$ & $\mathrm{D}$ & $\mathrm{T}$ & $\mathrm{D}$ & $\mathrm{T}$ & $\mathrm{D}$ & $\mathrm{T}$ \\
\hline \multirow[t]{3}{*}{$\mathrm{HbOC} /$ saline } & $<0.01$ & & $<0.01$ & & $<0.01$ & & $<0.01$ & & $<0.01$ & \\
\hline & $<0.01$ & & $<0.01$ & & $<0.01$ & & $<0.01$ & & $<0.01$ & \\
\hline & $<0.01$ & & $<0.01$ & & $<0.01$ & & $<0.01$ & & $<0.01$ & \\
\hline \multirow[t]{3}{*}{$\mathrm{HbOC} / \mathrm{DT}$} & $<0.01$ & $<0.10$ & 0.56 & 0.72 & 5.40 & 1.80 & 3.28 & 1.94 & 4.43 & 1.09 \\
\hline & $<0.01$ & $<0.10$ & $<0.01$ & 0.32 & 2.20 & 2.58 & 1.20 & 1.45 & 2.99 & 1.40 \\
\hline & $<0.01$ & $<0.10$ & 0.52 & 0.29 & 7.56 & 1.14 & 6.44 & 0.78 & 6.75 & 1.19 \\
\hline \multirow[t]{3}{*}{$\mathrm{HbOC} / \mathrm{T}$} & $<0.01$ & $<0.10$ & $<0.01$ & 0.29 & $<0.01$ & 1.60 & $<0.01$ & 0.74 & $<0.01$ & 0.66 \\
\hline & $<0.01$ & $<0.10$ & $<0.01$ & $<0.10$ & $<0.01$ & 0.44 & $<0.01$ & 0.44 & $<0.01$ & 0.53 \\
\hline & $<0.01$ & $<0.10$ & $<0.01$ & 0.75 & $<0.01$ & 2.61 & $<0.01$ & 1.44 & $<0.01$ & 1.67 \\
\hline
\end{tabular}

* Animals were injected on $\mathrm{d} 0,28$, and 56 . The HbOC dose contained $5 \mu \mathrm{g}$ of oligosaccharide and $12.5 \mu \mathrm{g}$ of CRM protein. The D dose contained $6.25 \mathrm{Lf}$ units and the T contained $2.5 \mathrm{Lf}$ units.

dependent on the immunogenicity of another vaccine to enable antibody formation.

The infant monkey model appears to be predictive of the iimmunogenicity of human infants to PRP-OMPC (9), and the immunogenicity profiles are the same in that good primary and booster responses are observed with PRP-OMPC (19). Earlier conjugate studies with a PRP/OMPC conjugate prepared by different chemical means showed that this conjugate was poorly immunogenic in human infants less than 16 mo of age (20). Subsequently, this conjugate was tested in infant rhesus monkeys and found to be nonimmunogenic after three doses (Vella PP, Ellis RW, unpublished data). On the other hand, the HbOC + DT group does not give a significant primary anti-PRP response after one dose but does induce good responses after the second dose with a boost in anti-PRP levels after the third dose, which is qualitatively equivalent to the profile of $\mathrm{HbOC}$ in human infants who do receive DTP concomitantly (21).

A previous study indicated that placentally transferred antibodies to diphtheria toxin of sufficient titer causes a reduced active immunization antibody response in human infants (22). This observation may explain why some human infants respond poorly or not at all to D during routine DTP immunizations.

Schneerson et al. (23) tested 5 and $50 \mu \mathrm{g}$ of PRP-T [which is immunogenic in human infants (24)] + pneumococcal 6A-T conjugates with and without concurrent administration of $\mathrm{T}$ ( 5 Lf units, at a separate site) in infant rhesus monkeys. Immunogenicity was relatively poor at both doses without concurrent administration of $\mathrm{T}$. Although a $\mathrm{T}$ priming effect was observed with $5 \mu \mathrm{g}$ of PRP-T, there was no further increase in antibody in the 50- $\mu$ g PRP-T group. The maximal anti-PRP titer observed after three doses of 5 or $50 \mu \mathrm{g}$ and concurrent $\mathrm{T}$ was low $(\leq 1.61$ $\mu \mathrm{g}$ anti-PRP/mL).

In summary, our data indicate that PRP-OMPC independently induces in immunologically naive infant rhesus monkeys serum anti-PRP levels that are above the level thought to be protective $(\geq 1.0 \mu \mathrm{g} / \mathrm{mL})$ in humans, whereas $\mathrm{HbOC}$ alone is not immunogenic after three doses. However, $\mathrm{HbOC}$ is immunogenic only when administered concurrently with DT at a separate site. Inasmuch as some children do not respond to $\mathrm{D}$ or do not receive the full complement of DTP vaccines during the first year of life, the role of concurrently administered DTP in the immune response generated in human infants by $\mathrm{HbOC}$ would be useful information.

Acknowledgments. The authors thank K. Dolan, J. Staub, and S. Szymanski for their technical support; W. Hurni for preparing radiolabeled ${ }^{125}$ I-PRP; W. E. Greer and his staff at the New Iberia Research Center for conducting the monkey immunizations and bleedings; R. N. Hamburger and his staff at Advanced Allergy Management Laboratory, La Jolla, California for their perform- ance of the anti-D and anti-T assays; $M$. Liu for a critical review of the manuscript; and D. Wilson for preparation of the manuscript.

\section{REFERENCES}

1. Dajani AS, Armar BI, Thirumoorthi MC 1979 Systemic Haemophilus influenzae disease: an overview. J. Pediatr 94:355-364

2. Fraser DW, Darby CP, Koehler RE, Jacobs CF, Feldman RA 1973 Risk factors in bacterial meningitis: Charleston County, South Carolina. J. Infect Dis 127:271-277

3. Marwick C 1985 FDA soon to license $H$. influenzae vaccine. JAMA 253:12321233

4. Parke Jr JC, Schneerson R, Robbins JB 1972 The attack rate, age, incidence, racial distribution, and case fatality rate of Haemophilus type b meningitis in Macklenburg County, North Carolina. J Pediatr 81:765-769

5. Hill JC 1983 Summary of a workshop on Haemophilus influenzae type b vaccines. J Infect Dis 148:167-175

6. Peltola H, Kayhty H. Sivonen A, Makela, PH 1977 The Haemophilus influenzae type b vaccine in children: a double-blind field study of 100000 vaccinees 3 months to 5 years of age in Finland. Pediatrics 60:730-737

7. Robbins JB 1978 Vaccines for the prevention of encapsulated bacterial diseases: current status, problems and prospects for the future. Immunochemistry 15:839-854

8. Kayhty H, Peltola H, Karanko V, Makela, $\mathrm{PH} 1983$ The protective level of serum antibodies to the capsular polysaccharide of Haemophilus influenzae b. J. Infect Dis 147:1100-1103

9. Vella PP, Staub JM, Armstrong J, Dolan KT, Rusk CM, Szymanski S, Greer WE, Marburg S, Kniskern PJ, Schofield TL, Tolman RL, Hartner F, Pan Sh, Gerety RJ, Ellis RW 1990 Immunogenicity of a new Haemophilus influenzae type $\mathrm{b}$ conjugate vaccine (Meningococcal protein conjugate) (PedvaxHIB ${ }^{\omega}$ ). Pediatrics 85(suppl):668-675

10. Marburg S, Jorn D, Tolman RL, Arison B, McCauley J, Kniskern PJ, Hagopian A, Vella PP 1986 Biomolecular chemistry of macromolecules: synthesis of bacterial polysaccharide conjugates with Neisseria meningitidis membrane protein. J. Am Chem Soc 108:5282-5287

11. Anderson P 1983 Antibody responses to Haemophilus infuenzae type b and diphtheria toxin induced by conjugates of oligosaccharides of the type $b$ capsule with the nontoxic protein CRM $_{197}$. Infect Immun 39:233-238

12. Tudor-Williams G, Frankland J, Isaacs D, Mayon-White RT, Macfarlane JA, Rees DG, Moxon ER 1989 Haemophilus influenzae type b vaccine trial in Oxford: implication for United Kingdom. Arch Dis Child 64:520-524

13. Ward Jl, Greenburg DP, Anderson PW, Burkart KS, Christenson PD, Gordon LK, Kayhty H, Juo JSC, Vella P 1988 Variable quantitation of Haemophilus influenzae type $\mathrm{b}$ anticapsular antibody by radioantigen binding assay. J Clin Microbiol 26:72-78

14. Bazaral M, Goscienski PJ, Hamburger RN 1973 Characteristics of human antibody to diphtheria toxin. Infect Immun 7:130-136

15. Myers MG, Beckman CW, Vosdingh RA, Hankins WA 1982 Primary immunization with tetanus and diphtheria toxoids. JAMA 248:2478-2480

16. Porro M, Saletti M, Nencioni L, Tagliaferri L, Marsilli I 1980 Immunogenic correlation between cross-reactive material (CRM197) produced by a mutant of Corynebacterium diphtheriae and diphtheria toxoid. J Infect Dis 143:716724

17. Donnelly JJ, Deck RR, Liu MA 1990 Mechanisms of immunogenicity of a Haemophilus influenzae polysaccharide-Neisseria meningitidis outer membrane protein complex conjugate vaccine. Vaccines 90: Modern approaches to new vaccines including prevention of AIDS, Cold Spring Harbor Laboratory Press, Cold Spring Harbor, New York, pp 419-424

18. Gold E, Fevrier A, Hatch MH, Herrmann KL, Jones WL, Kurgman RD, Parkman PD 1973 Immune status of children one to four years of age as 
determined by history and antibody measurement. N Engl J Med 289:231235

19. Ahonkhai VI, Lukacs LJ, Jonas LC, Matthews H, Vella PP, Ellis RW, Staub JM, Dolan KT, Rusk CM, Calandra GBl, Gerety RJ 1990 Haemophilus influenzae type $\mathrm{b}$ conjugate vaccine (meningococcal protein conjugate) (PedvaxHIB ${ }^{\omega}$ ): clinical evaluation. Pediatrics 85(suppl):676-68

20. Tai JY, Vella PP, McLean AA, Woodhour AF, McAleer WJ, Sha A, DennisSykes C, Hilleman MR 1987 Haemophilus infuenzae type b polysaccharideprotein conjugate vaccine. Proc Soc Exp Biol Med 184:154-161

21. Madore DV, Johnson CL, Phipps DC, Pennridge Pediatric Associates, Popejoy LA, Eby R, Smith DH 1990 Safety and immunologic response to Haemophilus influenzae type $\mathrm{b}$ Oligosaccharide-CRM ${ }_{197}$ conjugate vaccine in 1 - to 6-month-old infants. Pediatrics 85:331-337
22. Osborn JJ, Dancis J, Julia JF 1952 Studies on the immunology of the newborn infant. II. Interference with active immunization by transplacental circulating antibody. Pediatrics 10:328-333

23. Schneerson R, Robbins JB, Chu C, Sutton A, Vann W, Vickers C, London WT, Curfman B, Hardegree MC, Shiloach J. Rastogi SC 1984 Serum antibody responses of juvenile and infant rhesus monkeys injected with Haemophilus type b and pneumococcus type $6 \mathrm{~A}$ capsular polysaccharideprotein conjugates. Infect Immun 45:582-591

24. Claesson BA, Schneerson R, Robbins JB, Johansson J, Lagergard T, Taranger J, Bryla D, Levi L, Cramton T, Trollfors B 1989 Protective levels of serum antibodies stimulated in infants by two injections of Haemophilus influenzae type b capsular polysaccharide-tetanus toxoid conjugate. J Pediatr 114:97100 